\title{
Efforts to Control Potential Hazards of Working at Height at a Gresik Fertilizer Company, Indonesia
}

\section{Upaya Pengendalian Potensi Bahaya Bekerja Pada Ketinggian di Perusahaan Pupuk Gresik, Indonesia}

\author{
Dana Aprilia ${ }^{1}$, Aziz Ramadhan ${ }^{2}$ \\ ${ }^{1}$ Department Occupational Safety and Health, Faculty of Public Health, Airlangga University, \\ Campus C Mulyorejo, Surabaya, East Java, 60115 Indonesia \\ ${ }^{2}$ Fire and Safety Study Program, Balongan Oil and Gas Academy \\ Pekandangan, Indramayu, West Java, 45216 Indonesia
}

\begin{abstract}
Introduction: As one of the largest fertilizer industrieswith high competitiveness and high interest from consumers, the Gresik Fertilizer Company has various potential hazards that can cause workplace accidents, one of which is the danger of working at height. This study aims to determine the Occupational Safety and Health (OSH) programs and the application of hazard control of working at height in the Gresik Fertilizer Company. Methods: This study used a descriptive analysis method with a cross sectional study design. The variables studied were the hazard control efforts, the procedures to control the hazard, and the application of the hazard control process of working at height. Data collection techniques derived from secondary data in the form of company's documents, and the data analysis method used in this study was in the form of qualitative method. Results: the Gresik Fertilizer Company has several OSH programs for the control of hazard of working at height with a success rate of $90 \%$, have control methods of working at height with a success rate of $90 \%$, and have guidelines for working at height with a success rate of $85 \%$. Conclusion: The Gresik fertilizer company has OSH programs to control working at height, has hazard control methods for working at height, and guidelines for working at height.
\end{abstract}

Keywords: control efforts, fertilizer company, working at height hazards

\section{ABSTRAK}

Pendahuluan: Sebagai salah satu industri pupuk terbesar, berdaya saing tinggi, dan paling diminati konsumen perusahaan pupuk Gresik mempunyai berbagai potensi bahaya yang dapat menimbulkan kecelakaan kerja, salah satunya ialah bahaya bekerja pada ketinggian. Penelitian ini bertujuan untuk mengetahui progam-program keselamatan dan kesehatan kerja (K3) dan penerapan pengendalian bahaya bekerja pada ketinggian yang ada di perusahaan pupuk Gresik. Metode: Penelitian ini menggunakan metode deskriptif analisis dengan desain studi cross sectional, variabel yang diteliti yaitu upaya program pengendalian bahaya, prosedur upaya pengendalian bahaya, dan penerapan proses pengendalian bahaya bekerja pada ketinggian pada perusahaan pupuk di Gresik. Teknik pengumpulan data berasal dari data sekunder berupa dokumen perusahaan serta metode analisis data yang digunakan dalam penelitian ini berupa metode kualitatif. Hasil: Perusahaan pupuk memiliki beberapa upaya program K3 pengendalian bahaya bekerja pada ketinggian dengan capaian 90\%, memiliki metode upaya pengendalian bekerja pada ketinggian dengan capaian 90\%, dan memiliki pedoman bekerja pada ketinggian dengan capaian 85\%. Simpulan: Perusahaan pupuk Gresik memiliki program K3 pengendalian bekerja pada ketinggian, memiliki metode pengendalian bahaya bekerja pada ketinggian, dan menerapkan pedoman bekerja pada ketinggian yang telah ditetapkan perusahaan pupuk Gresik.

Kata kunci: bahaya ketinggian, perusahaan pupuk, upaya pengendalian

\section{Corresponding Author:}

Dana Aprilia

Email: dana.aprilia-2018@fkm.unair.ac.id

Telephone: +6281377264191

\section{INTRODUCTION}

Occupational Safety and Health (OSH) is part of public health science. One of its roles is protecting company assets, including protecting its workforce. Work safety must also be carried out to protect people or workers from work accidents 
due to potentially unsafe facilities, equipment or work environment. Meanwhile, work accidents are undesirable things which can cause both material and non material losses (Nurmianto, Anita and Aulia, 2018).

Health is a healthy state, both physically, mentally, spiritually and socially that enables everyone to live productively, socially, and economically (Minister of Manpower Regulation, 2009). The main priority in running OSH is to prevent occupational accidents and occupational diseases. Therefore, before starting a job, workers must first know the working conditions, causes and impacts that can arise so that workers can feel comfortable and safe at work (International Labour Organization, 2013).

In the world of industry, OSH is the most important thing that must be considered because it is related to human health and safety, both for workers and residents who live in the surrounding environment. This needs special attention because the accidents not only cause loss of life and material but also the disruption of the production process, which ultimately impacts on society and the environment (Nurmianto, Anita and Aulia, 2018). In short, OSH is an effort to create protection and security from various risks of accidents and hazards, both physical, mental and emotional hazards to workers, companies, communities and the environment (Martalina, Yetti and Lestari, 2018).

This is in accordance with the Law of the Republic Indonesia Number 1 of 1970 which states that "Every worker has the right to get protection for safety in doing work and everyone who is in the workplace needs to be guaranteed as well as safety and every source of production needs to be used and used safely and efficiently so that the production process runs smoothly" (Minister of Manpower Regulation, 1970).

Every year work accidents occur at work that cause fatalities, material damage and even production disruptions. According to The 2011 Health and Safety Statistics, 171 workers died at the workplace with an average of 0.6 fatalities per 100,000 workers. The construction, agriculture and disposal sectors were the largest contributors, accounting for 50,34 million and 9 fatalities and 115,379 other workers were injured, causing 4.4 million lost workdays (Shofiana, 2015).

Based on data from the International Labor Organization (ILO) in 2013, one worker in the world dies every 15 seconds due to work accidents and 160 workers suffering from occupational diseases. It is estimated that there were 337 million occupational accidents, and 2.3 million workers die every year due to occupational accidents and diseases (Martiwi, Koesyanto and Pawenang, 2017).

In Indonesia, work accident cases show an upward trend. Data of the Social Security Agency (BPJS) for Employment in 2011 showed that there were 99,491 occupational accidents, and this figure increased into 103,074 occupational accidents in 2012. Meanwhile, according to the ILO, in 2013 there were work accidents every day, resulting in fatal fatalities of around 6,000 cases (Wahyuadi, Kurniawan and Ekawati, 2016).

Working from height is a form of work that has the potential to fall in danger. It was further explained by the Rope and Work Corporation that working at height is a high-risk activity that requires special knowledge and expertise to carry out the job. In the world of construction, falling from height is the biggest contributor to accidental deaths (Shofiana, 2015). In addition, a report from the Workplace Safety and Health Council stated that falling from height is the largest contributor to occupational accidents caused by working at height. There were 126 occurrences of falling from height between 1998 and 2008 (Dyanita, 2018).

Gresik Fertilizer Company is one of the largest fertilizer industries in Indonesia, a subsidiary of the Indonesian fertilizer company. The company won the "Zero Accident" award, but behind the award there are problems related to OSH, namely unsafe behavior, unsafe conditions related to production processes and other activities. In the last six months there has been one work accident, which was a fall from height, and the accident was in the fatal category in the form of the death of a worker at that location.

Gresik Fertilizer Company is divided into several departments. Each department produces different types of fertilizers, namely organic and inorganic fertilizers. In increasing the quantity and quality of its production, the company seeks to maintain the performance of employees and the factory production process so that the company can run well.

As one of the largest fertilizer industries in Indonesia, the fertilizer company located in the city of Gresik has various types of potential hazards that can cause occupational accidents and increase life or material losses. One of the dangers in the company is working at height. 
The type of work at height has a considerable risk. Workers can fall because of differences in height which can result in death if workers do not comply with the rules set by the company.

According to the law of the Republic of Indonesia Number 9 of 2016 about Occupational Safety and Health Working at Height, working at height is defined as an activity which is carried out by workers at the surface of the land or waters where there is height difference and the potential to fall, so it can cause labor injury, death or damage to property (Regulations, 2016).

Another source said that working at height is a job categorized as "Class 1 Risk Activities". Reported from the Labor Force Survey (LFS2) in the United Kingdom, one of the causes of work accidents that can result in serious injuries to death is mostly in the construction sector of $11 \%$, and the type of work accident is falling from height of $31 \%$ (Sujono, 2018).

The incident of workers falling from height is the largest type of work accident in the construction world. Some of the potential hazards of working at height are falling objects, falling on the surface (slipping), falling from equipment, falling from scaffolding, falling from open objects, and spraining (Shofiana, 2015).

A study by Syahputra and Sulaksmono (2014) on the fertilizer industry showed a worker died because of falling from height while working in a boiler. Another study by Asriani, Hasyim and Purba (2011) in the urea unit of a fertilizer company stated that there were 4 cases of work accidents occurring in 3 years, which also resulted from workers falling from height.

Research by Hutajulu (2018) stated that two workers died due as they fell while welding iron docks in the fertilizer warehouse. Meanwhile, in this Gresik Fertilizer Company, it is known that for one year there was one worker who fell from height to death.

From this case, the researchers were interested in conducting research on the efforts that could be made in dealing with the dangers of working at height or in reducing casualties due to working at height at a Gresik fertilizer company. The purpose of this research is to find out the hazard control effort program, the hazard control effort procedure, and the application of the hazard control effort process to work at heights at a Gresik Fertilizer Company.

\section{METHODS}

The method used in this research was descriptive observational method with a cross sectional approach because this method describes a phenomenon that occurs in the community and is carried out at a certain time (Notoatmodjo, 2012). The study was conducted at a fertilizer company from June 1 to 30,2017 . The variables used in the study were the hazard control efforts, control procedures and the application of hazard control process in work at height.

The data used in the study were secondary data from company documents and supporting references in the Department of a Gresik fertilizer company. The data obtained were then analyzed descriptively to describe the conditions that existed in the company clearly., such as what OSH programs were implemented, what work control methods were used in working at height, and how working at height was guided so that it was safe.

\section{RESULTS}

\section{Identification of Occupational Hazards of Working at Height}

Potential hazards that can cause workers to fall from height include activities such as, installation or unloading of scaffolding, installation of frame conveyors, installation and release of roller supports, installation of bracing, erection and welding, finishing and painting, replacement of fiber with polycarbonate, and cleaning tube exchangers. The following figures show the types of working at height.

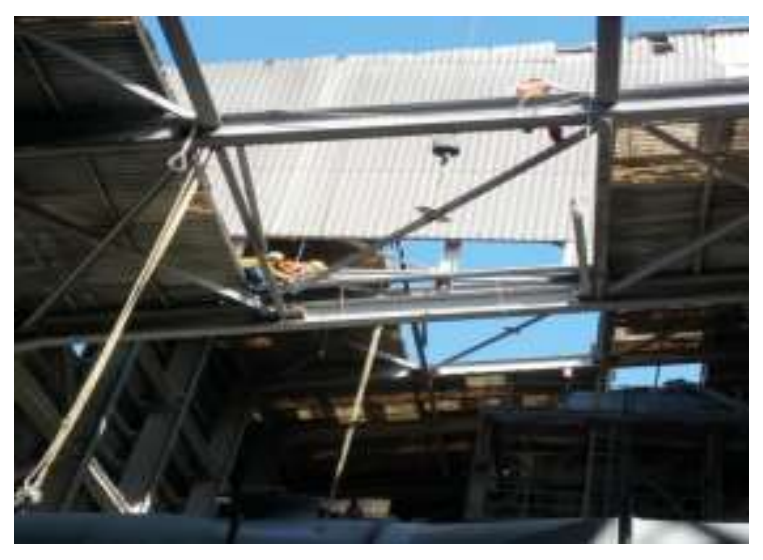

Figure 1. Installation of Bracing on the Roof Cover in a Gresik Fertilizer Company in 2017 


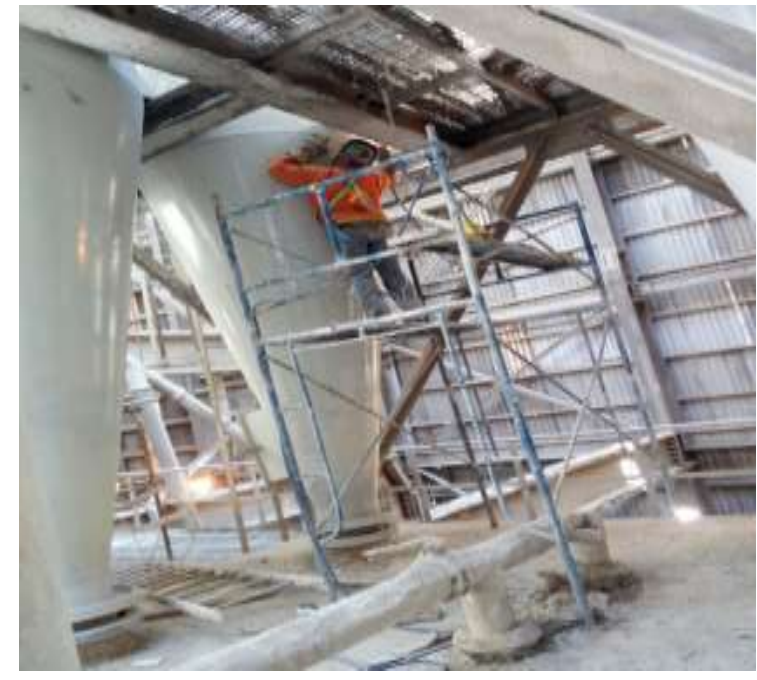

Figure 2. Welding Support Roller at a Gresik Fertilizer Company in 2017

\section{OSH Programs to Control the Potential Hazards of Working at Height}

The Gresik fertilizer company has already had OSH programs to control the danger of working at height. The programs in question include safety talk, safety induction, safety patrol, drill, and safety sign. These programs are based on relevant laws and regulations and in accordance with company policy. These programs have achieved $90 \%$ progress in preventing workers from falling at heights. These results are based on document studies that have been measured using questionnaires, observations, and interviews with the Gresik Fertilizer Company.

\section{Safety Talk}

Safety talks are held by the company before the work starts and are delivered along with the daily work plan that will be carried out to prevent work accidents. The program is implemented by a safety representative or safety officer. Safety talks are delivered together with a briefing before the work starts. This activity aims to remind workers about the importance of maintaining job security for the benefit of the company and themselves.

The activity greatly affects the number of work accidents at the Gresik Fertilizer Company. Results obtained are very significant in preventing work accidents, especially working at heights. This can be seen from the safety officer or safety representative who routinely conducts safety talks to workers. Safety talks discuss about matters regarding OSH, such as current issues, regulations, potential hazards, work procedures and recommendations for the use of

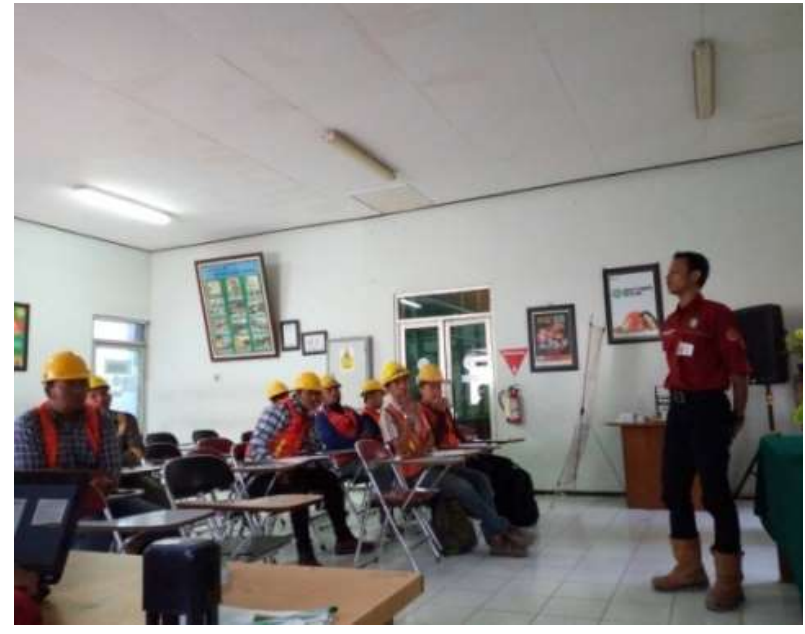

Figure 3. The delivery of safety induction to contractors and sub-contractors of the Gresik Fertilizer Company in 2017

personal protective equipment (PPE) very precisely such as full body seat belts, seat belts, safety straps, and anchor points. This is done because the company often found workers who do not want to use PPE

The topics of safety talks are in accordance with the location and job, and are delivered in clear language so that is easy for workers to implement. In addition, the safety team records the results of the safety talks including the topic of discussion, the date of implementation, and the names of the workers who have participated in the safety talks.

\section{Safety Induction}

Apart from safety talks, safety induction is a OSH socialization program which is held every day. This activity is implemented for guests or contractor workers who will enter the work area of the Gresik Fertilizer Company to maintain safety during their activities at the factory. Safety induction is carried out by safety officers and assisted by other OSH staff. The contents of the safety induction include a company profile, company OHS policies, work safety standards, PPE that must be used, hazards at work, company insurance prohibitions, first aid in accidents, and work safety related programs.

The results obtained are very significant in preventing work accidents, especially working at height. This can be seen from the fact that workers who have received safety induction are able to apply the directions given so as to prevent work accidents. In addition, this program is useful as workers are often worried about their safety and are afraid of loose sanctions by the company. However, in this 
safety induction activity, no post-test or pre-test activity is carried out by the company to review the knowledge of guests or employees.

\section{Safety Patrol}

Safety patrols are one of the OSH socialization programs that give significant impacts as new findings that will be followed up. This program is implemented every day, usually during the day. The activity is carried out by going around each area and looking for findings that are not in accordance with the Standard Operating Procedures. Then, the non-conforming conditions are reported and presented at the OSH meeting. The safety patrols are implemented by the OSH committee, the head of the work unit, and the safety representatives of each factory. The tools used to conduct safety patrols are observation sheets, stationery and documentary evidence. Various findings that are often found are contractor workers who do not use complete personal protective equipment when working at height or work equipment that must be contacted immediately.

These results are followed up in various ways, such as reporting to the head contractor or providing direct directions to the workers concerned. The warning is in the form of a written letter or notification informing workers to work according to procedures and comply with existing safety regulations. If the worker is unable to be warned and continues to carry out unsafe behavior, the worker is called by the head operator and is given a warning.

However, if the worker continues to violate the contractor's regulation, he will be blacklisted by the contractor working with the company. This program has been running well, where this program is always carried out every working day by the safety team to control and supervise workers so that they can work according to procedures and comply with existing $\mathrm{OSH}$ regulations. The OSH program socialization at the Gresik Fertilizer Company is interrelated so that one program must complement each other.

\section{Drill Training}

As one of the largest fertilizer companies in Indonesia, the Gresik fertilizer company surely has many potential hazards including fire. In this factory, drill training gives significant impacts in overcoming occupational accidents. This can be seen from several cases of work accidents at high, including the burning of rolls on the conveyor belt due to heat friction, boiler explosion due to excess pressure, and leakage of ammonia pipe welding which causes an explosion.

Workers who have passed will be certified in the area of emergency response by the relevant authorities. Activities in the training include lectures, brainstorming, pre and posttests, and emergency simulations. In addition, the fire department at the Gresik Fertilizer Company also cooperates with other companies if the fire department is unable to extinguish the fire.

Once a month, fire simulations are carried out to continuously hone workers' skills. Meanwhile, the drill training program has been implemented by the company, and the program is carried out once a year. This is done with the aim of training workers in dealing with fires, those operating both the Portable Fire Extinguishers and Hydrants.

These fire fighting drills include fire prevention, fire suppression and fire evacuation. The equipment owned by the company includes fire clothes, fire extinguishers, fire trucks, fire hydrant systems, and fire alarm systems. In addition, it has an API system panel, kitchen protection system, FM200 fire extinguishing system, spray nozzle, jet nozzle, fire housing, fire housing coupling, hydrant valve and Siamese connection, and water monitors.

\section{Safety Sign}

One way to control hazards or accidents at work is to use a safety sign. Safety signs and occupational health warnings are very important in terms of OSH communication so that workers always know the risks at work and can predict what needs to be done.

The work safety sign program at the Gresik Fertilizer Company has been implemented well. Safety signs are placed in a place that everyone can see and read clearly. Safety signs contain all information related to work safety, which is presented in a graphic form that illustrates safety messages at work. At present, the use of safety signs and warnings has become an integral part of workers' lives. This is done in order to maintain the security and safety of the workforce. The manufacture of the safety signs in the company is based on the American National Standards Institute (ANSI) Z535.

Safety signs give a very impact in preventing accidents from working at height. This can be seen from the understanding and application of workers who have read the safety signs well so that the number of falls from height can be suppressed. 


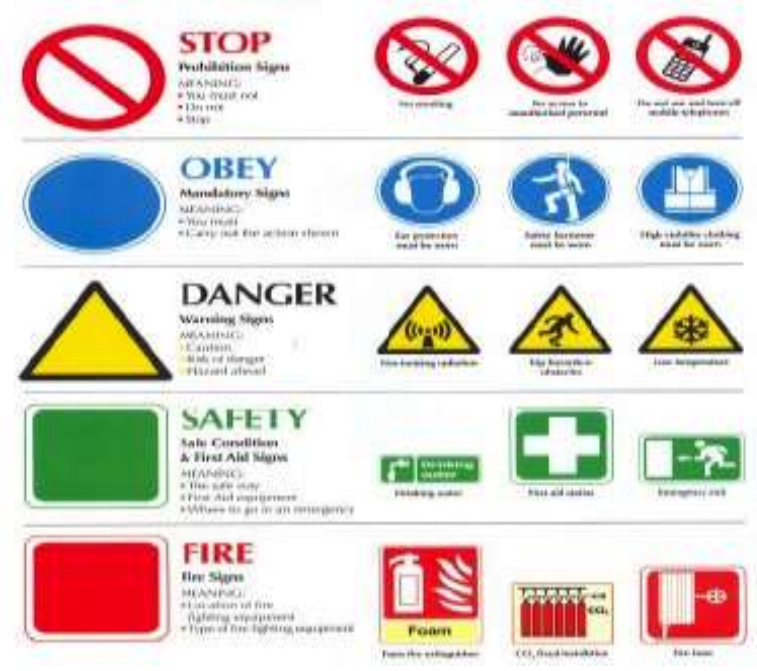

Figure 4. Safety Signs at the Gresik Fertilizer Company in 2017

In addition, there is an effective delivery of OSH communication which strengthens the safety signs, which is easy to do.

The safety sign socialization is carried out regularly in several activities such as safety talks, safety briefings, and safety patrols led by the OSH committee and safety officers or safety representatives. Workers are also given modules related to various types of safety signs and their functions so that they can greatly assist workers in understanding safety sign information. Furthermore, repair of the safety signs is carried out if it is damaged, carried out based on the safety officer or safety representative's report. This repair is carried out by a third party appointed by the Gresik Fertilizer Company.

\section{Methods (Tools) for Control of the Potential Hazards of Working at Height}

The Gresik fertilizer company has some control tools for potential hazard of working at height such as JSA, HIRADC, and work permit systems. The program has achieved $90 \%$ success in preventing workers from falling from height. These results are based on document studies that have been measured using questionnaires, observations, and interviews with the Gresik Fertilizer Company.

\section{$J \boldsymbol{S A}$}

JSA implementation at the Gresik Fertilizer Company is conducted with various related sectors. JSA is prepared by a team, depending on the work that will be made by JSA. JSA implementation is

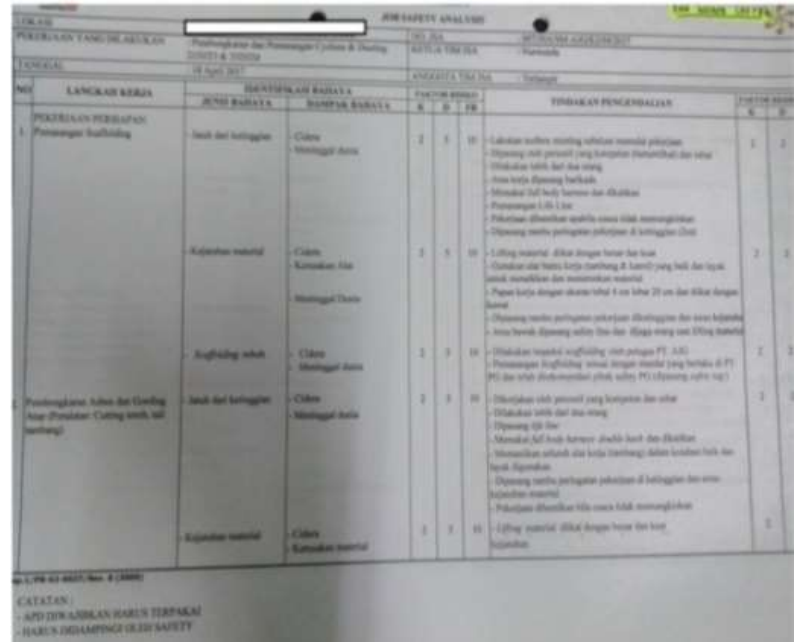

Figure 5. JSA at the Gresik Fertilizer Company in 2017

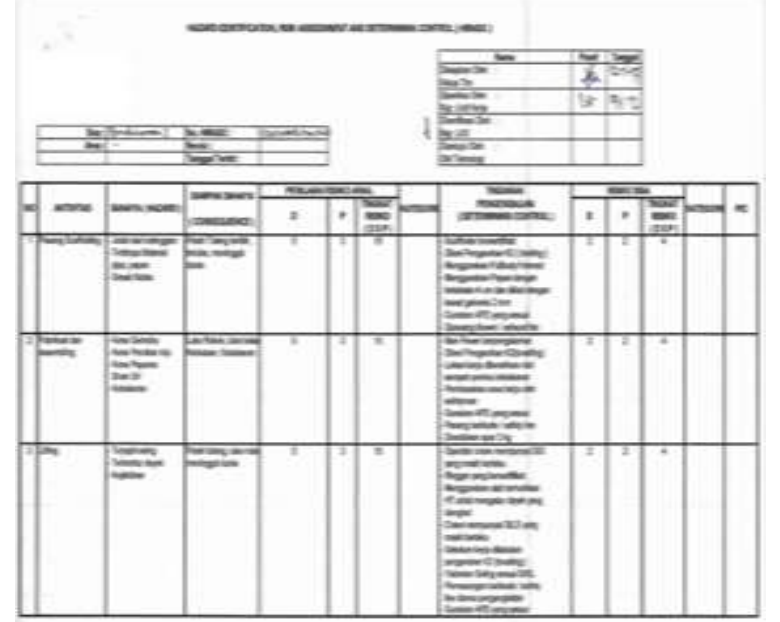

Figure 6. HIRADC at the Gresik Fertilizer Company in 2017

implemented by officers in the related work area, $\mathrm{OSH}$ and Environment team, supervisors, and engineers. If the work is internal, then the party which makes JSA is the OSH planning unit of the Gresik Fertilizer Company itself. However, if it is external, cooperation from several parties concerned is required. JSA reviews are conducted every six months.

The results of the JSA will be recorded and socialized to all workers who are doing the related work. If there is an error or deficiency in the making of the JSA, it will be revised by the relevant party and then legalized by the Head of the Department of $\mathrm{OSH}$ and Environment.

In practice, JSA at the Gresik Fertilizer Company has been implemented well. This program 
is very significant in preventing high work damage. This is supported by the commitment of OSH management which has implemented the OHSAS 18001 and ISO 45001 systems.

\section{HIRADC}

In making HIRADC, the Gresik Fertilizer Company has formed a team consisting of OSH and Environment team, one OSH staff, one technical person who is suitable for the job, and one or more supervisors. HIRADC reviews are conducted every six months. HIRADC is very significant in preventing work accidents, especially working at height. It can be seen from the HIRADC form that each work has been identified as a hazard; a risk assessment is carried out until appropriate control measures are in place. The results of HIRADC are distributed and disseminated to workers for evaluation materials for worker safety.

\section{Work Permit System}

A safety permit provides a very significant impact in preventing accidents from working at height. This can be seen from the awareness of workers to fill out the safety permit form before doing work that is potentially dangerous. The validity period of a work permit at the Gresik Fertilizer Company depends on the need for work or a maximum of seven days, and the validity period of a work permit is one work shift.

Work permits are issued by supervisors to contractors or workers who will enter hazardous areas or carry out work deemed hazardous. Before

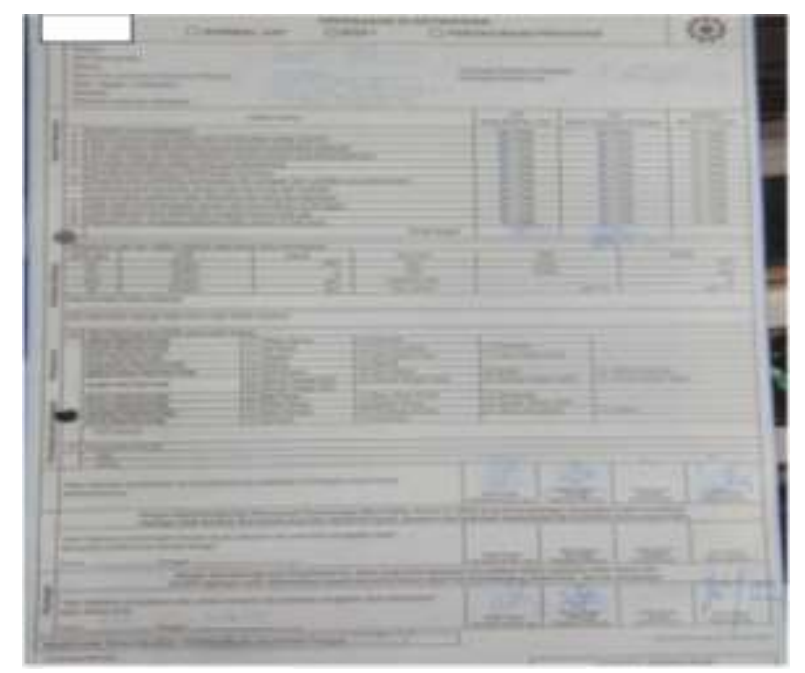

Figure 7. Work Permit System at the Gresik Fertilizer Company in 2017 granting a work permit, the supervisor will conduct an examination covering the health of the workers, the completeness of work facilities and infrastructure including PPE, and current conditions at the job site.

The safety permit verification process at the Gresik Fertilizer Company requires every worker to fill out a work permit form before working. Then, the work permit is signed by the contractor as the document maker and the safety officer as the examiner, and later it will be approved by the QSE Manager of the Gresik Fertilizer Company.

\section{Guidelines for Control of the Potential Hazards of Working at Height}

Gresik Fertilizer Company has regulated hazard control in accordance with the Regulation of the Minister of Manpower Number 9 of 2016 concerning Occupational Safety and Health at Height. In its implementation, the company determines a person or team from the work unit who is responsible for implementing it, including $\mathrm{OSH}$ and the environment, as well as various parties who work with the Company. Standard Operating Procedures are reviewed once a year for improvement.

The scope of the Standard Operational Procedure which contains objectives, scope, definitions, references, systems (including equipment and supplies, procedures and stops, etc.) distribution and socialization. This procedure has achieved $85 \%$ success in preventing workers from falling from height. These results are based

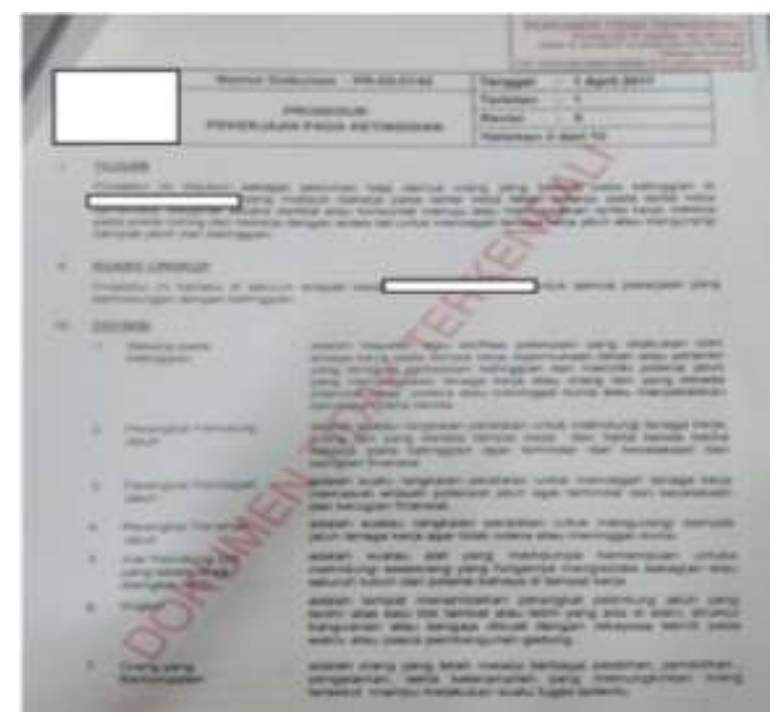

Figure 8. Procedure of Working at Height in the Gresik Fertilizer Company in 2017 
on document studies that have been measured using questionnaires, observations, and interviews withthe Gresik Fertilizer Company. The results of the SOP are reported by the Department of OSH and the environment.

\section{DISCUSSION}

\section{OSH Programs to Control the Potential Hazards of Working at Height}

Several OSH programs owned by Gresik fertilizer companies include:

\section{Safety Talk}

Gresik Fertilizer Company implemented a safety talk which is held before work starts to prevent work accidents, especially working at height. This is in line with research conducted by Kurniawan, Setyaningsih and Wahyuni (2013) which stated that a safety talk is a way to remind or make workers aware of occupational safety and health. A safety talk is a very important part of the job because it is needed to provide information / insight to workers who need to work healthily and safely in the workplace.

In another research, Candra and Ruhyandi (2008) stated that the company "X" must maintain safety talks for its workers in order to work in accordance with applicable work procedures, especially the use of PPE. This is also in accordance with research by Cunningham and Jacobson (2018) suggesting that workers really need knowledge to maintain a self-awareness of the benefits of using PPE in the workplace.

A safety talk is a weapon for understanding the seriousness of behavior change. In addition, companies must direct a more effective strategies to assist workers in all work activities, especially compliance with the use of PPE.

\section{Safety Induction}

Safety inductions are carried out every day to maintain the safety of all factory employees especially from working at height. Based on research conducted by Mutwale-Ziko, Lushinga and Akakandelwa (2017), safety induction can increase knowledge of safety for employees. In construction projects, this program reduces the risk of injury to employees. The provision of knowledge of hazards in the workplace can provide additional information to employees so that worker performance is more optimal, especially if it is done every day.

This activity is in accordance with Law Number 1 of 1970 Article 9 paragraph 1 concerning Safety and Work at the Workplace at Height so that with safety induction work accidents can be controlled. Besides, it is stated that company management is obliged to show and explain to every new worker regarding conditions and hazards in the workplace, all necessary safety and protective equipment as well as PPE and a safe attitude in carrying out work (Minister of Manpower Regulation, 1970).

\section{Safety Patrol}

The Gresik Fertilizer Company conducts safety patrols every day to look for any findings in the field that can cause work accidents, especially from working at height. This is in accordance with Ardina (2012) who stated that the implementation of safety patrols implemented every day will prevent work accidents due to unsafe conditions and actions in the company.

The result of this study is also in line with research of Ko, Student, and Lee (2018) which stated that the company formed a contract agreement with a third party/work partner to bring the safety patrol team to the construction site. This activity is a preventive strategy to reduce accident rates by changing bad behavior and unsafe situations. Safety at a construction site can be significantly improved by using human resources rather than machines, improving working environment conditions and giving priority to safety patrol teams for companies in the construction sector.

\section{Drill Training}

The company has firefighters who have been trained and certified by the authorized institutions in preventing fires or fighting fires. This is in accordance with research by Sambada, Kurniawan and Suroto (2016) which stated that drill training aims to improve the abilities, skills, alertness, insight and awareness of workers or firefighters about how they have to do the right job to prevent fires.

This statement is supported by research of $\mathrm{Li}$ and Xiao (2018) which stated that all employees must be trained in various fields including fire alarm systems, procedure reports for each employee, types of potential emergencies, evacuation plans, and fire fighting procedures, both light and heavy procedures. 
Fire simulations at the Gresik Fertilizer Company are carried out once a year. This is not in accordance with Sari's (2010) research, which stated that to train the skills of firefighters and employees, emergency response simulations should be carried out once a year. Meanwhile, emergency response training is held every two years. This difference can be caused by several factors, including the magnitude of the potential hazards of each factory and the budget for conducting training or simulations.

\section{Safety Sign}

Safety signs at the Gresik Fertilizer Company provide very significant impacts in preventing work accidents, especially from working at height. The manufacture of the safety signs in the company is based on the American National Standards Institute (ANSI) Z535. ANSI explains the hazards and ways to overcome these hazards to prevent work accidents. This is proven by Saputra's (2017) research, stating that the application of the safety sign based on ANSI Z535 at the research location is in accordance with the standards so that work accidents can be minimized. This happens because it is easy for workers to clearly understand the safety signs installed in the work area. Safety signs contain information about the source of the hazard, things that may cause a hazard, the effects inflicted from these dangers, as well as actions that must be done to protect danger.

Based on a study by Talab and Azari (2017) about Safety Sign Perception and Adoption with ISO and ANSI Standards on workers it is stated that the overall level of safety sign perception was $78.4 \%$ with a standard deviation of $15.1 \%$.

\section{Methods (Tools) for Control of the Potential Hazards of Working at Height}

Methods (tools) for efforts to control hazards of working at height aim to enable workers to comply with prescribed work steps so that workers can avoid work accidents and also to serve as a legal umbrella for the company.

These methods are control measures that have been prepared by the company. Control procedures have been socialized and given to each worker and the contractor/partner concerned. The following is a list of methods used to control the hazards of working at height at the Gresik Fertilizer Company:
$J S A$

The JSA in the Gresik Fertilizer company has been well implemented. The program is very significant in preventing work accidents of working at high. This is supported by the commitment of OSH management which has implemented the OHSAS 18001 and ISO 45001 systems.

The program is in line with Purnamasari's (2010) research on the application of Job Safety Analysis as an effort to prevent work accidents in the Picklend Section of PT. X. The results of this study stated that with Job Safety Analysis, workers can work safely and comfortably, know more about the dangers that exist in every job, know and implement recommended control measures, as well as improve their awareness of the importance of Occupational Health and Safety (Bawang, Kawatu and Wowor, 2018).

The JSA evaluation in this company is carried out every six months to make improvements for the smooth running of work and worker safety. This is in accordance with the research report by Mirnayanti and Prasetyo (2017) which stated that the JSA evaluation was carried out every six months to review work so that companies and workers could anticipate in preventing accidents.

\section{HIRADC}

HIRADC at the Gresik Fertilizer Company brings many benefits to prevent work accidents at height. According to Muhanafi (2015), HIRADC is one of the important points in implementing the Occupational Safety and Health Management System (SMOSH) in companies that provide workers with a feeling security and protection.

This activity is a framework for implementing good safety management practices.

Muhanafi's research (2015) at PT. "X" showed that the existence of HIRADC is able to detect the root of the problems that occur in every job, including workers who are not careful at work, unsafe work environment, and unsafe work equipment or machines. The roots of the problem are then analyzed to produce recommendations. With the HIRADC, a job can identify potential hazards that may arise so that the company can provide proper control, and work safety can be carried out by workers.

HIRADC reviews are conducted every 6 months. This is in line with Nurjanah's (2012) research, suggesting that the implementation of 
reviews is carried out every 6 months when there are inappropriate hazard conditions and control measures, there are changes in the production process, there are findings from audits, and there are work accidents occurring.

\section{Work Permit System}

The work permit system has a tremendous impact on the company in preventing work accidents at high. This statement is supported by the results of research of Khaqim (2014) which stated that the incidence of work accidents decreased after a safety permit was enforced at PT. "X". Before implementing the work permit system from 2004 to 2006 there were 138 cases of work accidents. Then, in 2007 to 2014 after the work permit system was implemented, the number decreased by $19.56 \%$, namely 101 cases of work accidents.

This result is also in accordance with Salmah and Lubis's (2016) research on the prevention of work accidents by using the Permit to Work and Hazard and Operability Study (HAZOP) system on boilers, which stated that work permits and the HAZOP system can prevent the occurrence of work accident levels. The validity period of the work permit depends on the needs of the work involved, or a maximum of seven days. If it exceeds the stipulated time, the work permit system must be extended again. The work permit system is an effective tool for identifying and managing hazards so that workers are able to avoid accidents, especially for workers who work at height.

\section{Guidelines for Control of the Potential Hazards of Working at Height}

The Gresik Fertilizer Company has a very high concern for the problem of work accidents. This is done for the safety and health of workers because workers are a very valuable asset in the company. Therefore, is the guidelines are very necessary for workers who work at height to avoid danger. Guidelines for working at a height at Gresik Fertilizer Company include:

\section{Standard Operating Procedures (SOP) of Working at Height}

The Gresik Fertilizer Company has procedural guidelines for each job. This is very beneficial for the safety of workers because there are work procedures so that they can avoid work accidents or occupational diseases. With these procedures, accidents at the Gresik Fertilizer Company can be minimized. manual procedure is updated annually and reported to the relevant Department.

This statement is in accordance with research of Gabriele (2018) statting that the implementation of standard operating procedures at PT. " $\mathrm{X}$ " has been running and implemented every day, and standard operating procedures have been socialized to every employee. The existence of a Standard Operating Procedure will help the company achieve its goals. To achieve the company goals, the company provides a draft in the form of an SOP that will guide employees in carrying out their duties and minimize errors in carrying out their respective duties.

This is in accordance with Barizqi's research (2015) at PT. "X" project. The relationship value obtained in this study was $(0.000<0.005)$, which means that there was a significant relationship between SOP compliance with accidents. It is stated that the application of Operational Standards had a positive and significant effect on productivity. The more obedient the worker, the smaller the number of work accidents and vice versa. Work procedures must be adhered to and implemented strictly in accordance with those imposed in the new era because doing work that is not in accordance with the new job can result in failure of the production process, damage to equipment and work accidents.

\section{CONCLUSION}

The Gresik fertilizer company has OSH programs in the form of safety talks, safety induction, safety patrols, drill training, and safety signs to control the hazard of working at height. The Gresik fertilizer company has some methods (tools) to control hazards of working at height in the form of JSA, HIRADC, and work permit system. The Gresik fertilizer company has guidelines for control of the potential hazards of working at heights, namely Standard Operational Procedures.

\section{ACKNOWLEDGEMENTS}

The researchers would like to thank the parties who have helped in the process of completion of this article. In addition, we would like to thank the extended family of the Department of Occupational Safety and Health (OSH) at the Faculty of Public Health, Airlangga University, who have provided guidance so that this article could be completed on time. 


\section{REFERENCES}

Ardina, S. A. (2012) Penerapan Safety Patrol Di PT. Toyota Motor Manufacturing Indonesia Karawang Plant. Undergraduate Thesis. Surakarta: Faculty of Medicine, Universitas Sebelas Maret.

Asriani, M., Hasyim, H., and Purba, I. (2011) 'FaktorFaktor Yang Berhubungan Dengan Perilaku Tidak Aman (Unsafe Act) di Bagian Pabrik Urea PT. Pupuk Sriwidjaja Palembang', Jurnal Ilmu Kesehatan Masyarakat, 2(2), pp. 103-109.

Barizqi, I. N. (2015) Hubungan Antara Kepatuhan Penggunaan APD Dengan Kejadian Kecelakaan Kerja Pada Pekerja Bangunan PT . Adhi Karya Tbk Proyek Rumah Sakit Telogorejo Semarang. Undergraduate Thesis. Semarang: Faculty of Sport Science University of Negeri Semarang.

Bawang, J., Kawatu, P. A. T., and Wowor, R. (2018) 'Analisis Potensi Bahaya Dengan Menggunakan Metode Job Safety Analysis Di Bagian Pengapalan Site Pakal PT. Aneka Tambang Tbk . UBPN Maluku Utara', Jurnal KESMAS, 7(5), pp. 1-13.

Candra, E. and Ruhyandi. (2008) 'Faktor Faktor Yang Berhubungan Dengan Perilaku Kepatuhan Penggunaan APD Karyawan Bagian Press Shop di PT. Almasindo II Kabupaten Bandung Barat Tahun 2008', Jurnal Kesehatan Kartika Stikes A. Yani, pp. 29-44.

Cunningham, T. R. and Jacobson, C. J. (2018) 'Safety Talk and Safety Culture: Discursive Repertoires as Indicators of Workplace Safety and Health Practice and Readiness to Change', Annals of Work Exposures and Health, 62(1), pp. 55-64.

Dyanita, F. (2018) 'Kepatuhan Terhadap Sop Ketinggian Pada Pekerja Konstruksi', The Indonesian Journal of Occupational Safety and Health, 6(2), p. 225.

Gabriele (2018) 'Analisis Penerapan Standar Operasional Prosedur (SOP) Di Departemen Marketing dan HRD PT. Cahaya Indo Persada', Agora, 6(1), pp. 1-10.

Hutajulu, R. A. R. (2018) Hubungan Tingkat Pengetahuan Penggunaan APD dengan Risiko Kecelakaan Kerja pada Pekerja di Unit Welding PT. Sumatera Maju Jaya Batam Tahun 2018. Undergraduate Thesis. Medan: Faculty of Public Health, University of Sumatera Utara.

International Labour Organization (2013) 'Keselamatan dan Kesehatan Kerja sarana untuk Produktivitas', Jakarta: International Labour Officee.
Khaqim, E. S. (2014) Analisis Sistem Ijin Kerja (SIKA) Terhadap Kejadian Kecelakaan Kerja Di PT . Bakrie Construction Serang Banten. Undergraduate Thesis. Surakarta: Faculty Health Science, University of Muhammadiyah Surakarta.

Kurniawan, W., Setyaningsih, Y., and Wahyuni, I. (2013) 'Hubungan Faktor Karakteristik Pekerja, Safety Morning Talk (SMT) dan HouseKeeping Dengan Kejadian Minor Injury Pada Pekerja di Proyek Pembangunan Gedung Kantor PT. X Jakarta', Journal of Chemical Information and Modeling, 5(3), pp. 323-331.

Ko, K.H., Student, G., and Lee, K.O. (2018) 'Determining Efficient Safety Patrol Team Operations on Construction Sites', Journal of Engineering and Applied Sciences, 13(9), pp. 2732-2736.

Li, N. F. and Xiao, Z. (2018) 'A Fire Drill Training System Based on VR and Kinect Somatosensory Technologies', International Journal of Online Engineering, 14(4), pp. 163-176.

Martalina, S., Yetti, H. and Lestari, Y. (2018) 'Identifikasi Bahaya dan Risiko Keselamatan Kerja Pada Saat Overhaul di Area Kiln PT. X tahun 2017', Jurnal Kesehatan Andalas, 7(1), pp. 14-18.

Martiwi, R., Koesyanto, H. and Pawenang, T. (2017) 'Faktor Penyebab Kecelakaan Kerja Pada Pembangunan Gedung', Higeia Journal of Public Health Research and Development, 1(4), pp. 61-71.

Minister of Manpower Regulation (1970) 'No. 1 Tahun 1970 Tentang Keselamatan Kerja', Jakarta: Minister of Manpower Regulation.

Minister of Manpower Regulation (2009) 'No. 36 Tahun 2009 Tentang Kesehatan', Jakarta: Minister of Manpower Regulation.

Mirnayanti, A and Prasetyo, E. (2017) Evaluasi Penerapan Job Safety Analysis (JSA) di Bagian Produksi Unit Paper Mill 7/8 PT. Pura Barutama, Prociding HEFA, pp. 24-29

Muhanafi, M. Y. (2015) Penerapan Hazard Identification, Risk Assesment and Determining Control Dalam Upaya Mengurangi Kecelakaan Kerja di PT Wijayakarya Beton PPB Majalengka. Undergraduate Thesis. Surakarta: Faculty of Health Science, University of Muhammadiyah Surakarta.

Mutwale-Ziko, J., Lushinga, N. and Akakandelwa, I. (2017) 'An Evaluation of the Effectiveness of Health and Safety Induction Practices in the 
Zambian Construction Industry', International Journal of Health and Medical Engineering, 11(3), pp. 584-588.

Notoatmodjo, S. (2012) Metodelogi Penelitian Kesehatan. Jakarta: Rineka Cipta.

Nurjanah, J. A. (2012) Penerapan Hazard Identification Risk Assesment and Determining Control ( Hiradc) Pada Pekerjaan Baru Sebagai Upaya Pencegahan Kecelakaan Kerja Di PT. Eastern Logistics Lamongan. Undergraduate Thesis. Surakarta: Faculty of Medicine, University of Sebelas Maret Surakarta.

Nurmianto, E., Anita, N. and Aulia, A. N. (2018) 'Identifikasi Hazard Dan Perancangan Sistem Informasi Keselamatan Dan Kesehatan Kerja Di Unit Amoniak (Studi Kasus : PT. Petrokimia Gresik)', Jurnal Manajemen dan Teknik, 8(2), pp. 112-122.

Purnamasari, D. (2018) Penerapan Job Safety Analysis sebagai Upaya Pencegahan Kecelakaan Kerja di Bagian Pickled PT. Adi Satria Abadi Yogyakarta. Special Report. Surakarta: Faculty of Medicine, Universitas Sebelas Maret.

Regulations (2016) 'No. 9 Tahun 2016 Tentang Keselamatan dan Kesehatan Kerja Dalam Pekerjaan di Ketinggian', Jakarta: Regulations.

Salmah, U. and Lubis, A. M. (2016) Sistem Permit to Work. Undergraduate Thesis. Medan: Faculty of Public Health, University of Sumatera Utara.

Sambada, G.H., Kurniawan, B., and Suroto. (2016) 'Analisis Sistem Tanggap Darurat Kebakaran di Container Yard 02 Terminal Petikemas PT. Pelabuhan Indonesia III (Persero) Semarang Tahun 2016', Jurnal Kesehatan Masyarakat (e-Journal), 4(4), pp. 667-672.

Saputra, F. E. (2017) 'Analisis Kesesuaian Penerapan Safety Sign Di PT. Terminal Petikemas Surabaya’,
The Indonesian Journal of Occupational Safety and Health, 5(2), p. 121.

Sari, L. M. (2010) Upaya Pencegahan dan Penanggulangan Potensi Bahaya Kebakaran di area outer tube casting pt. Kayaba Indonesia, Bekasi Jawa Barat. Undergraduate Thesis. Semarang: Faculty of Medicine, University of Sebelas Maret Surakarta.

Shofiana, I. (2015) Identifikasi Potensi Bahaya Pekerjaan Di Ketinggian Pada Proyek Pembangunan Gedung Parkiran Rumah Sakit Telogorejo (Studi Deskriptif Pada Proyek Konstruksi Oleh PT. Adhi Karya Semarang). Undergraduate Thesis. Semarang: Faculty of Sport Science, University of Negeri Semarang.

Sujono, R. (2018) Desain Alat Bantu Keselamatan dan Kegiatan Kerja Petani Cengkeh dengan Pendekatan User Centered Design. Undergraduate Thesis. Jogjakarta: Faculty of Industrial Technology, University of Islam Indonesia.

Syahputra, M.R. and Sulaksmono, M. (2014) 'Kelengkapan Pemenuhan Syarat Operator Ketel Uap Dengan Upaya Pengoperasian Dan Pemeliharaan Di PT. Pupuk Kaltim (Studi Pada Operator Di Industri Kimia)', The Indonesian Journal of Occupational Safety and Health, 3(2), pp. 201-211.

Talab, A.H.D., and Azari, G. R. (2017) 'Safety Sign Perception and Adoption with the ISO and ANSI Standards', Jundishapur Journal of Health Science, 9(4), pp. 1-6.

Wahyuadi, H. T., Kurniawan, B., and Ekawati, E. (2016) 'Analisis Implementasi Izin Kerja Di Ketinggian Terhadap Kecelakaan Kerja Di PT. X', Jurnal Kesehatan Masyarakat (e-Journal), 3(3), pp. 428-436. 